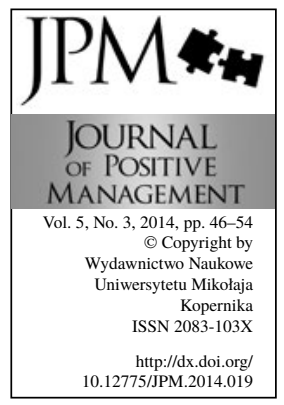

\title{
EMPLOYER BRANDING AS AN EFFECTIVE TOOL IN ACQUIRING TALENTS \\ Ewelina Wilska
}

Faculty of Economic Sciences and Management, Nicolaus Copernicus University,Torun, Poland, e-mail: ewelina.wilska@wp.pl

\begin{abstract}
The purpose of the following study is to demonstrate that employer branding is an effective tool in acquiring talents. The starting point to considerations is the analysis of terminology used in literature. Next, the strategy of employer branding is shown as the component of two complementary and long-term action plans. The first one is concerned with the improvement of talented workers' management system, and the latter deals with popularization of the execution of organization's best practices. What is emphasized in this study, is the importance of these two actions' consistency, which conditions acquiring talents as a long-term perspective.
\end{abstract}

Keywords: employer branding, talent, attract talent

Paper type: General review

\section{Introduction}

Employer's brand has not been given too much attention in Poland yet, and the most probable reason for this is the lack of translation of corporate image into financial results. Although $17 \%$ of Polish people have a degree in higher education, enterprises experience problems in finding suitable employees (GUS, 2012). The problem is getting worse especially that the days of mass personalization are setting in. It is manifested in both, consumers' requirements towards products and services customized to their individual preferences and lifestyle needs, and talented candidates who are not satisfied with their post, which is far from individually custom-made. Currently, the candidates seek employment with the employer's brand that fits their individual needs.

The purpose of the following study is to demonstrate that employer branding is an effective tool in acquiring talents. The starting point to considerations is the analysis of terminology used in literature. Next, the strategy of employer branding is shown as the component of two complementary and long-term action plans. The first one is concerned with the improvement of talented workers' 
management system, and the latter deals with popularization of the execution of organization's best practices. What is emphasized in this study, is the importance of these two actions' consistency, which conditions acquiring talents as a longterm perspective.

\section{What is employer branding?}

The beginning of the discussion of employer branding is worth mentioning one of the first definitions by Ambler and Barrow, who claims that employer brand is 'the set of functional, economical and psychological benefits, resulting from employment and being identified with the employing company' (Ambler and Barrow, 1996). A definition presented in such a way contains a lot of aspects, out of which all should express what the organization, as an employer, presents. These aspects cause a unit to aim at achieving the status of an employer by choice.

Having looked through literature, it can be noticed that a lot of definitions concerning the topic of employer brand need to be explained. According to the opinion and interpretation of Knox and Freeman, employment brand and employer brand are terms, which can be used interchangeably (Knox and Freeman, 2006) and relate to the same thing. Another terms used are employment branding and employer branding. When we analyze the way employment branding is perceived by Sullivan and Leigh, one can conclude that employment branding is equivalent in meaning to employer branding. Employment branding can be described as 'the process of introducing corporate image' or the picture of 'an ideal work place' in the minds of the target pool of candidates. It is a concept adopted from the business perspective of the company. On the other hand, product branding is based on developing a permanent picture in the minds of consumers, so that they can automatically make associations with the quality of each product or service provided by the brand owner. Employment branding consists in the same thing, namely creating an image, which makes people want to work in a well-managed organization, one which enables them to learn and self-develop (Sullivan, 2000). Sullivan bases his definition strictly on creating the image. Similarly as Sullivan, Martin stresses attracting talented employees to an organization with its corporate image; however, with a clear emphasis on identifying talents with a corporation, its brand and mission, and on delivering desirable effects (Martin, 2008).

It is worth underlining here, that creating employer's image, also named as building employer's brand, is inextricably connected with communication. It is particularly stressed by Jenner and Taylor, who define employer branding by indicating that a corporation makes an effort in order to communicate to the outside and inside public what makes this corporation a desirable and distinguished employer (Jenner and Taylor, 2008). Lloyd, who presents a similar attitude to the author of this study, claims that employer branding is "the sum of 
EMPLOYER

BRANDING AS AN

EFFECTIVE TOOL

Ewelina Wilska organization's efforts aimed at communicating to present and future employees, that the company is a desirable work place" (Moroko and Uncles, 2008).

\section{Does employer branding work in the context of acquiring talents?}

Barrow and Mosley, who are authors of numerous publications dealing with the topic of employer's brand building, demonstrate main advantages resulting from executing EB actions, the example of which are (Barrow and Mosley, 2005):

- Lower costs - as, generally speaking, the primary role of brands is creating added value, a strong employer's brand can contribute to decreasing costs in the areas of recruitment, employee retention or sick leaves;

- Customer satisfaction - the majority of research concerning the role of delivering customer satisfaction is focused on a wider concept of employees' involvement and commitment towards employer's brand;

- Financial results - both, reducing costs and increasing customer satisfaction ensure strong business justification for focusing on employer's brand. It is crucial to emphasize a distinct relationship between a strong employer's brand, high employees' involvement and financial results.

The authors pointed to the fact that strong employer's brand, connected with workers' above-average commitment, allows to cut costs, reinforce customer's satisfaction, and last but not least, contributes to achieving better financial results. Benefits in the form of an effective acquisition of talents ought to be recognized as general business benefits, which have essential impact on all organizations (Barrow and Mosley, 2005).

Considering another perspective, benefits from using employer branding include: firstly, creating the public image of the company, work culture, working methods, organizational style and employees' development perspectives. Secondly, employer's brand is integrated with the brand of the company and brands of its various products. Additionally, constant monitoring of the company's employment image, both inside and outside. Next, access to the stimulating and superb potential of candidates applying for a job in the company (Waghammer et al., 2013).

Herman and Gioia enumerated the following features, as qualities resulting from incorporating the strategy of building employer's brand (Herman and Gioia, 2001):

- reducing the costs of marketing and recruitment,

- optimization of results,

- higher quality and quantity of job applicants,

- reducing retention and increasing workers' loyalty,

- increasing efficacy, effectiveness and profitability,

- higher attractiveness to customers and investors.

An employer from choice or in other words "an employer with an established and strong brand, who work is something unique for. It is an enterprise which 
makes its employees self-assured and proud" (Wojtaszczyk, 2009) will clearly differentiate from his competition in respect to employing talented workers, regular customer and investor portfolio, and suppliers' environments. The mentioned diversity will build up a higher level of profitability, safety, and future success of an organization building the employer's brand (Herman and Gioia, 2001).

In 2012, LinkedIn ordered carrying out a survey among its world-wide users. Based on the analysis of over 7,000 questionaires, the survey enabled to draw a conclusion that a strong employer's brand has twice as big influence on attracting potential employees, rather than a general brand of an organization. Surely, there are companies, which can easily attract the best employees, on the basis of strong general brands; however, such companies are in minority. Investment in the employer's brand can be an effective way for the majority of enterprises to attract and influence talents of the highest rank. Strong employer's brand can have a real influence on potential candidates' interest in working for a company. It is worth emphasizing here, that a strong general brand of an organization definitely does not do harm in attracting the biggest talents, since it is one of the ways of providing talents with information through knowledge and experience included in its products and services. It makes it possible for a talented person to determine if a certain organization can be a good solution. Furthermore, research shows that concentration on employer's brand is particularly valuable for acquiring talents from the following groups of recipients (LinkedIn, 2012):

- Specialists and managers - employer's brand is almost three times more connected with the workplace consideration by this group of talents;

- Younger candidates - employer's positive image significantly impacts those potential candidates who are below 40 years old;

- More global: research results indicate a 37 per cent increase in decisionmaking, as far as choosing the place of work under the influence of employer's brand, with potential candidates from the outside of the USA;

- As the LinkedIn researchers confirm, companies with a strong employer's brand, boast a lower cost of acquiring talented candidates.

The result of research conducted among 32 Polish enterprises, chosen by daily "Rzeczpospolita" from the group of 2000 biggest companies, indicates, although to a smaller degree, a positive influence of EB on the effectiveness of acquiring talented employees (indication of 75 per cent). Nearly 63 per cent of indications concerned taking care of the company's image, as that of an attractive employer, and influencing the effectiveness of acquiring talents in at least high degree. However, close to 32 per cent of respondents assessed this impact on a moderate level. Benefits indicated by respondents mainly concern the following: decreasing costs of acquiring a worker, small values of fluctuation indicator, facilitated acquiring/attracting strategic partners and achieving competitive advantage. 
EMPLOYER

BRANDING AS AN

EFFECTIVE TOOL

Ewelina Wilska
One can venture to claim that there is strong evidence for employer branding to actually work. However, it is worth paying attention to the results of the next research, which demonstrated that the main reason for applying for a job in a particular workplace is location. Analysis of the survey results conducted by The CareerBuilder under the name Applicant Experience, made it possible to position reputation/brand on the third place, as regards to the most influential motivating factor. This allows us to assume that changing location to a more desirable one, will have a bigger influence on attracting talents, rather than on the improvement of the brand. Nevertheless, one has to consider the fact that it is not always possible to change location and branch of a certain industry, the latter being the second most attractive factor for candidates. Therefore, in this situation, reputation and brand can be the most changeable element of company's offer for a talented candidate.

\section{How to make employer branding effective?}

Global measurements carried out by Employer Brand International's (EBI) at the turning of 2012 and 2013, showed that 39 per cent of examined companies were planning to increase in 2013 investment expenditures on brand promotion (Strayer LaMotte, 2013). In order to stand out above the market, companies organize happenings, modernize office space and put more effort into preparation of, and running their website, which contains information about the company and its actions. Earlier research conducted in 2011 indicates that upon choosing an organization, the biggest number of candidates ( 86 per cent) pays attention first to career development opportunities, next to company's reputation and culture, and working environment (both having 84 per cent indications) (Employer Branding Online, 2011).

The presence of an attractive and up-to-date 'career' link on the company's website seems to be valid and essential. When a company places on its website a job offer for an ambitious project aimed at interns or trainees, it can present a detailed profile of the candidate they need. High requirements in the criteria for selection enable a potential talent to emerge. At this point, consistency between creating an attractive, external image and actions in the area of managing talents and culture, in other words internal elements of an individual, is of substantial importance. Lack of consistency, which can be seen as treating a trainee/intern as a full-time employee, without proper implementation and guidance, or as free workforce indispensable for assisting actions, can lead to negative social reaction, which can be revealed on social media forums or other forms of public communication. Acquiring talents by means of selected, individual actions which create a positive employer's external image, and in reality are unreliable, are definitely perceived as shortsighted actions. In further perspective they can backfire, which in the context of the example mentioned, can be seen when another 
recruitment advertisement is placed and HR department will not be receiving any applications from talented candidates (Smyk, 2011). When pursuing the construction of a desirable employer's image, organizations should consider the complexity of the process and necessity to take consistent actions in the context of entities and areas of activity (Chhabra and Aparna, 2008).

Experts in employer branding enumerate crucial elements for building employer's brand and actions connected with them:

1) Defining the company's profile - preparing credible information about the company for potential candidates, which will indicate further plans in organization's development;

2) Caring for reputation in the market - analysis of competition's position, analysis of reputation in the closest environment, assessment of ownbrand products and services' quality, assessment of actions concerning business' social responsibility;

3) Creating and maintaining the unique organizational culture - working out high standards in all fields of company's activity, employing only the best of potential candidates, propagating the atmosphere of openness and earnestness, treating senior workers with respect, supporting diversity;

4) Encouraging fun in and out of the workplace - introducing the atmosphere of enjoyment, celebrating all occasions;

5) Creating a strong support structure inside the organization - promoting co-operation between workers, providing support for individual workers who are in the middle of task execution;

6) Providing information technology support - implementing state-of-theart technologies, the purpose of which is to facilitate employees' work and co-operation regardless of the area in which they execute their tasks;

7) Eliminating status barriers - eliminating formal norms considering dress code, getting rid of hierarchical allocation of parking spaces, providing workers with constant access to current information about the enterprise, products and other employees;

8) Building success culture - promoting the best workers, so that they are recognized in the company, laying out high level of expected effectiveness, supporting innovation, precise assessment of employee's resources, research and development support;

9) Caring for effective ways of communication system - providing essential tools and limiting barriers to make communication between colleagues better;

10) Ensuring effective leadership - guiding towards the future, communicating the vision of the future to employees, providing the accessibility of managers, caring for direct contact with employees, delegating responsibility (Herman and Gioia, 2001). 
EMPLOYER

BRANDING AS AN

EFFECTIVE TOOL

Ewelina Wilska
A website called HRstandard.pl, which is dedicated to the area of Human Resources, presents a lot of interesting articles containing results of Polish and world-wide data analysis, also concerning the topic of employer branding. In the article titled " 83 per cent chance for a specialist. A brand different from any other", opinions of lots of practitioners are presented. They mainly involve factors, which motivate talented employees to choose a particular employer. For the best specialists, such determinants as participating in engaging and interesting projects, development opportunities, and atmosphere at work come before the remuneration. The next thing mentioned is taking socially responsible actions, which influences both: the way the employer is perceived, as frank and friendly, and building positive attitude among co-workers, which improves their motivation for doing everyday tasks, makes their creativity bigger, and what is more, integrates the team. A crucial factor is the workplace - a modern office block, built using green technologies and located in the vicinity of other prestigious brands. A workplace which calls up positive associations, builds trust and increases satisfaction from the job done (HRstandard.pl, 2013).

32 Polish enterprises from the list "Rzeczpospolita 2000" participating in the survey, most often put into practice the following external EB tools:

- updated 'career' link on the company's website with exhaustive job advertisement information (78 per cent indications),

- internet search engine advertisement (62 per cent),

- form and content attractive recruitment advertisements on job search portals or specialist media (62 per cent),

- information on the company's website including a scope of responsibilities of certain employees or teams, together with their current photographs (50 per cent),

- communication by means of professional and social networks (34 per cent).

\section{Conclusions}

To recapitulate the above considerations, which are based on strong statistic data, we can claim that a good brand is by all means worthwhile for the employer. Workers, who experience consistency of actions taken by the company in both areas: internal and external, are less willing to leave the company. Taking initiatives which are socially responsible increases employed workers' satisfaction, and makes a positive impression on candidates. All the mentioned actions influence the increase of commitment inside an organization, and also contribute to the growth in quantity and quality of candidates who apply to the company for various positions.

Before taking actions concerning creating the image of employer's brand, it is vital to lay out well our intended aims and ways of their verification. What we can 
use here are the following: indicators of retention, employees' commitment, quality of the employed workers, cost of acquiring a talented worker and the number of applications. It is possible to verify the actions we take, and possibly, adjusting them to the level of highest effectiveness by carrying out measurements. What distinguishes an organization from competition, and influences the decisions of the most talented candidates concerning their choice of a workplace, is possessing a positive image of employer's brand.

\section{References}

Ambler, T., Barrow, S. (1996), “The employer brand”, Journal of Brand Management Vol. 4 No. 3, pp. 185-206. DOI:http://www.dx.doi.org/10.1057/bm.1996.42

Barrow, S., Mosley, R. (2005), The employer brand: Bringing the best of brand management to people at work, Wiley \& Sons Ltd., London, pp. 69-74.

Chhabra, N.L., Aparna, M. (2008), "Talent Management and Employer Branding: Retention Battle Strategies", Journal of Management Research, Vol. 7 No. 11, pp. 50-61.

Employer Branding Online (2011), "Executives now challenging HR and Marketing for responsibility of the Employer Brand strategy", available at: http://www.employerbrandingonline.com/ news/research/346-new-research-findings-ebis-2011-employerbranding-global-research-study.html (accessed 18 September 2013).

Główny Urząd Statystyczny (2011), „Wyniki Narodowego Spisu Powszechnego Ludności i Mieszkań 2011. Podstawowe informacje o sytuacji demograficzno-społecznej ludności Polski oraz zasobach mieszkaniowych", p. 13, available at: http://www. stat.gov.pl/cps/rde/xbcr/gus/lu_nps2011_wyniki_nsp2011_22032012.pdf (accessed 20 September 2013).

Herman, E.R, Gioia, J.L. (2001), "Helping Your Organization Become an Employer of Choice", Employment Relations Today, Vol. 28 No 2, pp. 63-78. DOI:http://www. dx.doi.org/10.1002/ert.1015.abs

HRstandard.pl (2013), ,,83 proc. szansy na specjalistę. Marka inna, niż wszystkie”, available at:http://hrstandard.pl/2013/05/28/83-proc-szansy-na-specjaliste-marka-inna-nizwszystkie/ (accessed 19 September 2013).

Jenner, S.J., Taylor, S. (2008), "Employer branding - fad or the future of HR?" in: S. Humpage (Ed.) Research insight: employer branding: the latest fad or the future for HR? Chartered Institute of Personnel and Development, London, p. 7.

Knox, S., Freeman, C. (2006), "Measuring and managing employer brand image in the service industry", Journal of Marketing Management, Vol. 22 No 7, pp. 695-716. DOI:http://www.dx.doi.org/10.1362/026725706778612103

Martin, G. (2008), “Employer branding - time for some long and 'hard' reflections?", in: Employer branding. The latest fad or the future of HR?, research insight, Chartered Institute of Personnel and Development, London.

Moroko, L., Uncles M.D. (2008), "Characteristics of successful employer brands”, Journal of Brand Management, December 2008, Vol. 16 No. 3, pp. 160-175. DOI:http:// www.dx.doi.org/10.1057/bm.2008.4

Smyk, E. (2011), „Employer branding. Kilka uwag o budowaniu pozytywnego wizerunku 
EMPLOYER

BRANDING AS AN

EFFECTIVE TOOL

Ewelina Wilska firmy jako pracodawcy", available at: http://www.praktycznateoria.pl/employerbranding/ (accessed 18 September 2013).

Strayer LaMotte, S. (2013), "Employer Brand: It's What You Measure That Counts", available at: http://www.exaqueo.com/2013/02/employer-brand-its-what-you-measure-thatcounts/ (accessed 18 September 2013).

Sullivan, J. (2000), "Building an Employment Brand", in: P. Wesman (Ed.), The Right Communiqué, Second Quarter, Vol. 4 No 2, [from:] B. Leigh (2000), Keeping the People Who Keep You in Business: 24 Ways to Hang on to Your Most Valuable Talent, Amacom, New York, p. 18.

Waghamare, S., Shivashankar, S., Sheshrao, M., Reshma, S. (2013), 'Employer branding: a strategic tool to attract and retain talents in a competitive environment", Indian Streams Research Journal, Vol. 2 No 12, pp. 1-4.

Wojtaszczyk, K. (2009), „Od marki do marki pracodawcy z wyboru”, e-mentor, No. 1 (28), pp. $18-22$. 